\title{
Assessing The Maturity Level Of Information Technology Management Process In A Romanian Company
}

\author{
Minodora Ursacescu, The Bucharest University of Economic Studies, Romania
}

\begin{abstract}
Since the 1990s, organizations have gradually become involved in the transformation of their information technology (IT) management process. In order to determine the direction of IT development in correlation with business needs, a consolidated management approach is imposed. This paper aims to provide a comprehensive assessment of the maturity level of IT management process in an organization. For this purpose, an empirical study in a Romanian public service company was done by using the benchmarking technique and Capability Maturity Model to describe the maturity level of IT management process. Four benchmarking classes, including a number of 24 benchmarks, were taken into account to focus on the main key issues - IT management strategy and IT planning; alignment of business strategy, IT strategy, organizational structure, and IT infrastructure; and information systems security management. The study reveals that the IT management process is mainly focused on technological dimension and less on the managerial one. It was observed that IT managers have a low awareness of managerial skills in planning, organizing, controlling, and leading the IT activities. Practical implication of the study presents two major issues: 1) on one hand, the need to approach a transversal vision in managing the IT process by aligning it to a complex set of choices, reflecting both a strategic and functional perspective and, 2) on the other hand, this study may be useful for managers looking to improve management of the IT department as well as the quality of their services. The study also indicates specific recommendations to refine the IT management process of Romanian companies.
\end{abstract}

Keywords: Information Technology Management Process; Maturity Level; Business Strategy; Strategic Alignment

\section{INTRODUCTION}

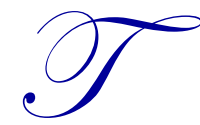

he main mission of the IT department is to support the organization's business processes and to improve their performance and competitiveness. For this reason, the IT management process is important for business management and it has to be aligned with general principles of corporate governance. Although most of the companies consider IT as an "organizational strategic player," IT management is different in private and public enterprises. The public services enterprises represent a substantial category, exercising activities in the area of services for local collectivities or in the infrastructure sectors like energy, transports, telecommunications, health, or education. Furthermore, these companies are sometimes characterized by an excessive intervention of the State that leads to some managerial dysfunctions (e.g., change of managerial team, lack of objectivity and transparency). In these conditions, managing IT activities in line with business objectives and a high level of quality services provided to customers must not only be understood, but constantly renewed and adjusted. This is reflected in opinions of CIOs, which suggest that the need of IT strategy integration into business strategy is a top management priority. Many CIOs will have to get answers on questions which are beyond the technological issues, such as lack of business alignment, top management's expectations concerning the use of ICT, or how the IT department should be managed. The IT function plays an important role in competitive advantage and in corporate agility (Goldman, Nagel, \& Preiss, 1995). Therefore, a main assumption can be underlined: the effectiveness of IT management process is a real stake for an organization that leads it to performance, productivity and progress. 
Starting from these general issues, the purpose of the paper is to assess the maturity level of an IT management process in a public service organization. The reason for choosing such a company is that public service organizations recognize the benefits of the IT management process, but they have difficulty in effectively aligning it within their business strategy. The analysis will be conducted in four areas, which are representative for the company, such as:

1. IT management strategy and information systems planning

2. Alignment of information systems, business strategy, organizational structure, and IT infrastructure

3. Software and hardware infrastructure

4. Information systems security management

An empirical study was conducted in this company in order to investigate 1) management of the IT department and ability of the organization to improve the strategic planning process for information systems, 2) the relationship between software/hardware infrastructure and its utility to satisfy the informational needs of organization, and 3) the management of information systems security.

\section{BACKGROUND AND LITERATURE REVIEW}

The IT management process has become an essential challenge for companies. The information systems are both the instrument to develop the organization's strategy and the source of competitive advantage. In this perspective, a new approach on IT management is imposed. Many researchers have accepted the view of a systemic approach to information systems which should be developed and managed in line with the strategic options of the organization. However, this is quite difficult to do because of two major obstacles. First, traditionally businesses are operated by dividing the organization into various functions (e.g., accounting, marketing, finance, human resources management, productions/operations management) in a silo structure with each having its own information systems and tending to work in isolation. Second, IT management is faced with the challenge of moving from a reactive to a proactive state in the strategic management of an organization. In order to deal with these problems, managers need to think on a cross management approach, which focuses on strategic alignment between business strategy, organizational structure, IT strategy, and IT infrastructure. According to Scott Morton (1991), the main objective is to build an organizational structure with the proper resources as well as the internal processes, which should, on the one hand, reflect the organization's strategy and, on the other hand, the information technologies this one wants to develop. To complete this opinion, a strategic alignment model is proposed by Henderson \& Venkatraman (1993) which has two fundamental dimensions:

- $\quad$ Strategic integration involving the alignment between business strategy and IT strategy - This relationship is necessary to strategically exploit IT potentials. Consequently, it is widely accepted that aligning IT and business strategies is important for achieving high performance levels.

- Functional integration involving the relationship between IT and business units - This implies that alignment mechanisms have to be considered and investigated at the operational level in order to be able to achieve the expected benefits from business-IT alignment.

In this context, the organization's economic performance directly depends on its capacity to develop a strategic fit between the position in the competitive environment and an appropriate IT structure to support its execution. The strategic alignment is a dynamic process, permanently adapted to the environment changes and thus aims to achieve the competitive advantage of the organization. This requires a high-level holistic perspective, enabling to lead IT managers to have a more business-focused approach.

It is widely recognized that IT management process is one factor that influences IT success. Many studies have focused on the important role of the owner and/or other senior managers. For example, Thong, Yap, \& Raman (1996) focused on top management support and its influence on IT success. Ifinedo (2008) states that top management support refers to the extent to which top managers in the organization provide direction, authority, and resources during and after the acquisitions of IT systems. However, a large body of literature has identified top management support as a critical success factor for IT projects (Davenport, 1998; Davenport, 2000; Somers \& Nelson, 2004). Although the concept of IT management has broadly explored by management literature, a consensus has not been reached with respect to the definition of this construct. An approach related on productivity, 
profitability and competitiveness as success factors for IT activities belongs to Badawy (1998) who affirms that IT management is concerned with exploring and understanding information technology as a corporate resource that determines both the strategic and operational capabilities of the firm in designing and developing products and services for maximum customer satisfaction, corporate productivity, profitability, and competitiveness. The IT management process is focused on the classical functions of planning, organizing, and controlling and should not be confused with Management Information Systems. This last concept is focused on strategic and contemporary uses of information systems, such as implementing enterprise planning systems, adopting customer relationship management systems, establishing knowledge management systems for better managing organizational knowledge resources (Xu \& Quaddus, 2013). Given the major changes in the global environment and the rapidly increasing set of options for information and communications technologies (ICT), several imperatives for the IT management process are imposed:

- To align IT strategy with the organization's business strategy: This action allows a consolidated management perspective that optimizes the mechanisms to effectively manage IT function through an integrated strategic management approach. Link (2008) states that an IT strategy warrants to top management that the IT systems provided are developed, deployed and managed in a robust manner and are in line with organizational aims and objectives.

- To develop an IT management strategy that improves business productivity and creates profitability: Commonly, many IT managers develop a strategy to resolve many or all problems at once. They are unable to correctly identify the objectives, to understand the business IT requirements, and to develop a holistic view of IT infrastructure.

- $\quad$ To design the IT infrastructure according to business strategy, IT strategy and organizational infrastructure and processes: This is done by considering three main elements. The first refers to architecture that defines the planned "shape" of the IT infrastructure; hardware and software are obviously part of this architecture. The second element establishes the standard technologies that are used to implement the architecture. Constant testing and screening of the technology market are required to determine the technologies that are conformed to information and processing needs of the organization. Finally, the third element refers to the value of IT infrastructure. This depends on management's strategic vision, as well as the types of IT services provided, and the consolidated budget of IT department. Some of the benefits of IT infrastructure management are reflected in the following: 1) combines IT and business processes and cross-organizational communication, 2) supports IT services with business objectives, and 3) promotes adaptability required for a changing environment (Choubey, 2012).

- To manage information system security: This is one of the most important issues that organizations are confronted with. Although information system security is increasingly being considered as an organizational issue, the protection of technological infrastructure is still the main goal. Therefore, the aspects related to management information security process or the IT risk management process are neglected.

Most organizations cannot align to these imperatives. The most important reason is founded rather in the low level of managerial capabilities, or leadership, than the effectiveness of IT function. However, the IT management process should be approached through the general functions of management, which are planning, organizing, controlling, and leading (Daft, 2011). These functions are well defined by management science, but their application in the information area is usually neglected. For great corporations, IT planning, IT organizing, and IT controlling are major dimensions that allow improving the performance of IT management. Moreover, IT leadership has been recognized as an important function that provides the knowledge, skills, and tools needed for a successful and dynamic IT leader (Karahanna \& Watson, 2006). Unfortunately, the small and medium-size firms do not widely recognize the importance of applying these functions to manage the IT activities. Most companies are dissatisfied with the value and contribution that IT is making to their business. Mature knowledge and understanding of such functions provides opportunities to implement particular actions for better management of IT activities.

\section{RESEARCH METHODOLOGY}

To achieve the purpose of this study, the benchmarking technique was adopted and was found to be useful for quantifying items that described the IT management process and for comparing the organization's practices with 
the best practices considered to be representative in the domain. The Capability Maturity Model (CMM) was applied to assess the maturity level for each benchmarking class, which allows identifying the most critical activities that affects the IT management process. Four benchmarking classes, including a number of 24 benchmarks, were taken into account to measure and analyze the maturity level reached by the company in the IT management process.

\section{Critical Criteria to Define Benchmarks}

Defining the most representative benchmarks that will be considered in this research should take into consideration a set of critical criteria which can be used as a guideline on how to select the appropriate benchmarks that provide a foundation for assessing the effectiveness of the IT management process. The author suggested seven critical criteria, which are shown on the left side of Table 1. It is important to consider these criteria by comparing them with standard criteria that describe the requirements of an organization for performance excellence. The Criteria for Performance Excellence adopted by Baldrige Performance Excellence Program (2012) is suggested as a potential tool to aid in this regard. Table 1 presents critical criteria that were selected to define the benchmarks and their relationship with Criteria for Performance Excellence, which serves as a foundation for the performance management system.

Table 1: Critical Criteria Compared to Criteria for Performance Excellence

\begin{tabular}{|l|l|}
\hline \multicolumn{2}{|c|}{ Critical Criteria } \\
$\begin{array}{l}\text { Commitment and support from top } \\
\text { management }\end{array}$ & $\begin{array}{l}\text { Leadership - role of senior leaders, vision and values, communication, } \\
\text { organizational performance. }\end{array}$ \\
\hline Planning and analysis & $\begin{array}{l}\text { Strategic Planning, Strategy development process, Strategic objectives, Strategy } \\
\text { implementation. }\end{array}$ \\
\hline Alignment of IT and business strategy & Strategic planning, Organizational governance. \\
\hline IT infrastructure & $\begin{array}{l}\text { Performance Measurement, Management of Information Resources and } \\
\text { Technology. }\end{array}$ \\
\hline Perceived IT utility & $\begin{array}{l}\text { Information analysis, Data and information availability, Process Management, and } \\
\text { Business Results. }\end{array}$ \\
\hline $\begin{array}{l}\text { Setting clear objectives and guidelines } \\
\text { for information security }\end{array}$ & $\begin{array}{l}\text { Strategic planning, Performance analysis, Performance Improvement, Emergency } \\
\text { Availability }\end{array}$ \\
\hline Perception of IT users & Work system Requirements, Work system Implementation, Work Process Design. \\
\hline
\end{tabular}

\section{Data Collection and Processing}

Data were collected through a questionnaire that reflects the weight of each benchmark in the benchmarking class (Table 2). The study included top- and mid-level managers from IT department as respondents, but also CEOs of company, IT consultants, and members of the organization's staff.

Table 2: Structural Benchmarks

\begin{tabular}{|l|c|}
\hline \multicolumn{1}{|c|}{ Benchmarking Class } & $\begin{array}{c}\text { Weight of Benchmark } \\
(\%)\end{array}$ \\
\hline Class 1. IT management strategy and information systems planning & 16 \\
\hline 1.1 IT management strategy is a systemic component of organizational strategy. & 22 \\
\hline $\begin{array}{l}\text { 1.2 Using the SWOT technique to identify strengths, weaknesses, threats and opportunities for IT } \\
\text { activities. }\end{array}$ & 12 \\
\hline 1.3 Anticipating business growth. & 10 \\
\hline 1.4 Implication of seniors executive in chart of IT department. & 8 \\
\hline 1.5 Managing expectations related to IT objectives across stakeholder groups. & 32 \\
\hline $\begin{array}{l}\text { 1.6 IT planning is based on a detailed written plan identifying requirements, time frame, cost } \\
\text { structure, personnel requirements and possible constraints. }\end{array}$ & \multicolumn{2}{|c|}{14} \\
\hline Class 2. Alignment of information systems, business strategy, organizational structure, and IT infrastructure. \\
\hline 2.1 Understanding the business requirements. & 16 \\
\hline 2.2 Developing a holistic view of IT infrastructure. & 18 \\
\hline 2.3 Strategic integration (strategic fit): correlation between business strategy and IT strategy. & 22 \\
\hline 2.4 Functional integration: integration between organizational structure and IT infrastructure. & 30 \\
\hline 2.5 Allocation of IT budgets such that business functions are supported in an optimal way. & \\
\hline
\end{tabular}


Table 2 cont.

\begin{tabular}{|l|c|}
\hline Class 3. IT infrastructure & \\
\hline $\begin{array}{l}\text { 3.1 IT infrastructure provides the assets, services, and resources for business innovation across the } \\
\text { organization. }\end{array}$ & 27 \\
\hline $\begin{array}{l}\text { 3.2 IT infrastructure is designed according to restrictions of costs (hardware costs, business } \\
\text { application costs, utility costs). }\end{array}$ & 36 \\
\hline $\begin{array}{l}\text { 3.3 Analyzing the business needs for IT (conceptualizing of IT applications, and delivery of } \\
\text { applications either through internal development, external contracting, or integration of packaged } \\
\text { software). }\end{array}$ & 15 \\
\hline $\begin{array}{l}\text { 3.4 The IT function is organized around the value-creating processes of infrastructure management, } \\
\text { financial management, strategic planning, and human capital management. }\end{array}$ & 8 \\
\hline $\begin{array}{l}\text { 3.5 Identifying the applicable IT components (hardware, software, configuration settings). } \\
\text { Class 4. Information systems security management }\end{array}$ & 5 \\
\hline $\begin{array}{l}\text { 4.1 Knowing the international standard for Information Security Management Systems (ISO/IEC: } \\
\text { 27002, 2003). }\end{array}$ & 9 \\
\hline $\begin{array}{l}\text { 4.2 Organizations of information security (the roles and responsibilities for information security). } \\
\text { 4.3 Asset management (responsibility for assets, information classification). }\end{array}$ & 11 \\
\hline $\begin{array}{l}\text { 4.4 Access control (user access management, user responsibilities, and system and application } \\
\text { access control). }\end{array}$ & 13 \\
\hline 4.5 Physical and environmental security (secure areas, equipment security). & 18 \\
\hline $\begin{array}{l}\text { 4.6 Operations management (protection from malware, control of operational software, technical } \\
\text { vulnerability management). }\end{array}$ & 23 \\
\hline 4.7 Communications security (network security management, information transfer). & 6 \\
\hline 4.8 Managing risk with security processes. & 15 \\
\hline
\end{tabular}

The respondents were asked to assess the benchmarks on a scale from 1 to 4 (where 1 means "not important," 2 means "less important," 3 means "quite important," and 4 means "most important"). The score gained from every respondent was acquired by summing the benchmarks' index on each class. Benchmarking class maturity level is obtained from each respondent. Table 3 shows an example of the questionnaire that reflects the perception of one respondent about the maturity level of the benchmarking class which affects the IT management process.

Table 3: An Excerpt of Benchmarking Class Maturity Level (One Respondent)

\begin{tabular}{|c|c|c|c|c|c|c|}
\hline \multirow[t]{2}{*}{ Structural Benchmarks } & \multirow[t]{2}{*}{$\begin{array}{c}\text { Weight of } \\
\text { Benchmark } \\
(W) \\
\end{array}$} & \multicolumn{4}{|c|}{$\begin{array}{l}\text { Answer Score } \\
\text { (S) }\end{array}$} & \multirow{2}{*}{$\begin{array}{c}\text { Benchmark } \\
\text { Index } \\
(\mathbf{B I}=\mathbf{W} * \mathbf{S})\end{array}$} \\
\hline & & $\begin{array}{c}\text { Not } \\
\text { important }\end{array}$ & $\begin{array}{c}\text { Less } \\
\text { important }\end{array}$ & $\begin{array}{c}\text { Quite } \\
\text { important }\end{array}$ & $\begin{array}{c}\text { Most } \\
\text { important }\end{array}$ & \\
\hline \multicolumn{7}{|c|}{ Class 1. IT management strategy and information systems planning } \\
\hline $\begin{array}{l}\text { 1.1 IT management strategy is a systemic } \\
\text { component of organizational strategy. }\end{array}$ & 16 & - & - & 3 & - & 0,48 \\
\hline $\begin{array}{l}1.2 \text { Using the SWOT technique to identify } \\
\text { strengths, weaknesses, threats, and } \\
\text { opportunities for IT activities. }\end{array}$ & 22 & - & 2 & - & - & 0,44 \\
\hline 1.3 Anticipating business growth. & 12 & - & - & 3 & - & 0,36 \\
\hline $\begin{array}{l}\text { 1.4 Implication of seniors executive in } \\
\text { chart of IT department. }\end{array}$ & 10 & - & - & 3 & - & 0,3 \\
\hline $\begin{array}{l}\text { 1.5 Managing expectations related to IT } \\
\text { objectives across stakeholder groups. }\end{array}$ & 8 & - & 2 & - & - & 0,16 \\
\hline $\begin{array}{l}\text { 1.6 IT planning is based on a detailed } \\
\text { written plan identifying requirements, time } \\
\text { frame, cost structure, personnel } \\
\text { requirements and possible constraints. }\end{array}$ & 32 & - & - & - & 4 & 1,28 \\
\hline Class 1 Maturity Level & & & & & & 3,02 \\
\hline \multicolumn{7}{|c|}{ Class 2. Alignment of information systems, business strategy, organizational structure, and IT infrastructure. } \\
\hline $\begin{array}{l}2.1 \text { Understanding the business } \\
\text { requirements. }\end{array}$ & 14 & - & 2 & - & - & 0,28 \\
\hline $\begin{array}{l}\text { 2.2 Developing a holistic view of IT } \\
\text { infrastructure. }\end{array}$ & 16 & - & 2 & - & - & 0,32 \\
\hline
\end{tabular}


Table 3 cont.

\begin{tabular}{|c|c|c|c|c|c|c|}
\hline \\
\hline $\begin{array}{l}2.3 \text { Strategic integration (strategic fit): } \\
\text { correlation between business strategy and } \\
\text { IT strategy. }\end{array}$ & 18 & - & - & 3 & - & 0,54 \\
\hline $\begin{array}{l}2.4 \text { Functional integration: integration } \\
\text { between organizational structure and IT } \\
\text { infrastructure. }\end{array}$ & 22 & - & - & 3 & & 0,66 \\
\hline $\begin{array}{l}2.5 \text { Allocation of IT budgets such that } \\
\text { business functions are supported in an } \\
\text { optimal way. }\end{array}$ & 30 & - & - & - & 4 & 1,2 \\
\hline Class 2 Maturity Level & & & & & & 3,00 \\
\hline \multicolumn{7}{|l|}{ Class 3. IT infrastructure } \\
\hline $\begin{array}{l}\text { 3.1 IT infrastructure provides the assets, } \\
\text { services, and resources for business } \\
\text { innovation across the organization. }\end{array}$ & 27 & - & - & 3 & - & 0,81 \\
\hline $\begin{array}{l}\text { 3.2 IT infrastructure is designed according } \\
\text { to restrictions of costs (hardware costs, } \\
\text { business application costs, utility costs). }\end{array}$ & 36 & - & - & - & 4 & 1,44 \\
\hline $\begin{array}{l}3.3 \text { Analyzing the business needs for IT } \\
\text { (conceptualizing of IT applications, and } \\
\text { delivery of applications either through } \\
\text { internal development, external contracting, } \\
\text { or integration of packaged software). }\end{array}$ & 15 & - & 2 & - & - & 0,3 \\
\hline $\begin{array}{l}3.4 \text { The IT function is organized around } \\
\text { the value-creating processes of } \\
\text { infrastructure management, financial } \\
\text { management, strategic planning, and } \\
\text { human capital management. }\end{array}$ & 14 & - & - & - & 4 & 0,46 \\
\hline $\begin{array}{l}\text { 3.5 Identifying the applicable IT } \\
\text { components (hardware, software, } \\
\text { configuration settings). }\end{array}$ & 8 & - & - & 3 & - & 0,24 \\
\hline Class 3 Maturity Level & & & & & & 3,25 \\
\hline \multicolumn{7}{|c|}{ Class 4. Information systems security management } \\
\hline $\begin{array}{l}\text { 4.1 Knowing the international standard for } \\
\text { Information Security Management } \\
\text { Systems (ISO/IEC: 27002, 2003). }\end{array}$ & 5 & - & 2 & - & - & 0,1 \\
\hline $\begin{array}{l}\text { 4.2 Organizations of information security } \\
\text { (the roles and responsibilities for } \\
\text { information security). }\end{array}$ & 9 & - & 2 & - & - & 0,18 \\
\hline $\begin{array}{l}\text { 4.3 Asset management (responsibility for } \\
\text { assets, information classification). }\end{array}$ & 11 & - & - & 3 & - & 0,33 \\
\hline $\begin{array}{l}\text { 4.4 Access control (user access } \\
\text { management, user responsibilities, and } \\
\text { system, and application access control). }\end{array}$ & 13 & - & - & 3 & - & 0,39 \\
\hline $\begin{array}{l}\text { 4.5 Physical and environmental security } \\
\text { (secure areas, equipment security). }\end{array}$ & 18 & - & - & - & 4 & 0,72 \\
\hline $\begin{array}{l}\text { 4.6 Operations management (protection } \\
\text { from malware, control of operational } \\
\text { software, technical vulnerability } \\
\text { management). }\end{array}$ & 23 & - & - & - & 4 & 0,92 \\
\hline $\begin{array}{l}4.7 \text { Communications security (network } \\
\text { security management, information } \\
\text { transfer). }\end{array}$ & 6 & - & - & - & 4 & 0,24 \\
\hline 4.8 Managing risk with security processes. & 15 & - & - & 3 & - & 0,45 \\
\hline Class 4 Maturity Level & & & & & & 3,33 \\
\hline
\end{tabular}

Nineteen respondents were involved in the study. The perception of all respondents concerning the maturity level of each benchmarking class is presented in the Appendix

It should be mentioned that the maturity level of each benchmarking class, which resulted from all the questionnaires, was added and divided by the number of respondents involved. An overall maturity level of the main class of processes that affect the effectiveness of the IT management process is shown in Table 4. 
Table 4: The Overall Maturity Level of Benchmarking Class

\begin{tabular}{|l|c|c|}
\hline \multicolumn{1}{|c|}{ Benchmarking Class } & $\begin{array}{c}\text { Number of } \\
\text { Respondents }\end{array}$ & $\begin{array}{c}\text { Overall } \\
\text { Maturity Level }\end{array}$ \\
\hline Class 1. IT management strategy and information systems planning & 19 & 1,89 \\
\hline $\begin{array}{l}\text { Class 2. Alignment of information systems, business strategy, organizational } \\
\text { structure, and IT infrastructure. }\end{array}$ & 19 & 1,84 \\
\hline Class 3. IT infrastructure & 19 & 3,14 \\
\hline Class 4. Information systems security management & 19 & 2,34 \\
\hline IT management process maturity level (ML) & & $\mathbf{2 , 3 0}$ \\
\hline
\end{tabular}

\section{RESULTS AND DISCUSSIONS}

In order to analyze the maturity level reached by the company in the IT management process, the Capability Maturity Model (CMM) was used. This model presents an evolutionary improvement path from an adhoc, immature process to a mature, disciplined process (Paulk, 1995). Each of five levels of CMM describes how the organization can operate to manage the IT process (Figure 1).

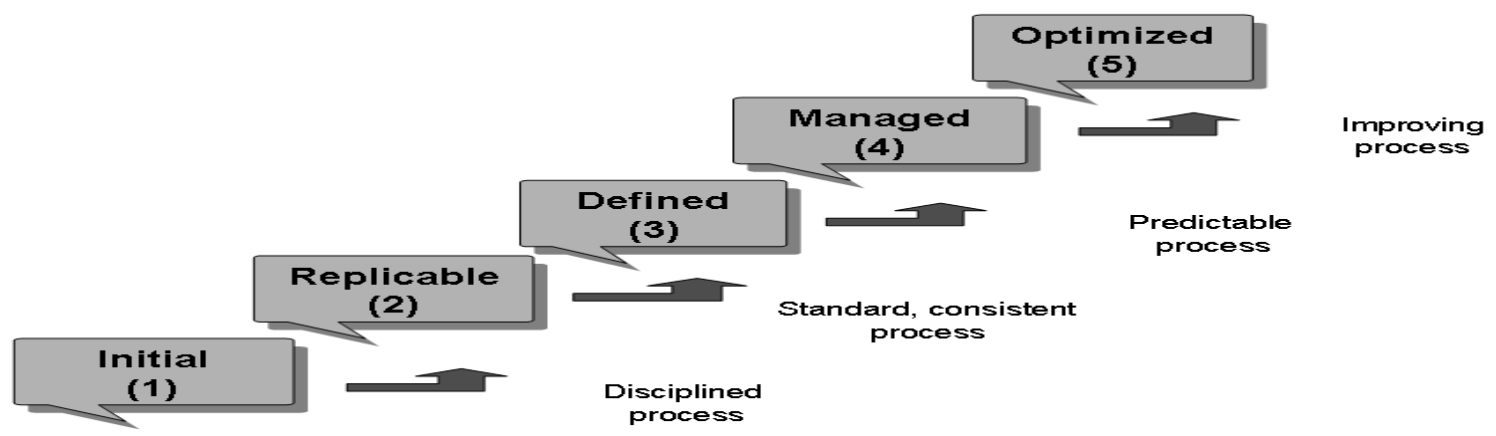

Figure 1: The CMM with Five Levels of Maturity Source: adapted from Paulk (1995)

Based on this maturity framework, the distribution of the overall maturity level of each benchmarking class was represented in five levels of the model by using the conversion system as shown in Table 5.

Table 5: The Conversion System

\begin{tabular}{|c|c|c|}
\hline Maturity Level (CMM) & Maturity Level Types & Conversion System \\
\hline 1 & Initial (Ad-hoc processes) & $0-1,0$ \\
\hline 2 & Replicable (Intention to do) & $1,1-2,0$ \\
\hline 3 & Defined (Most processes organized) & $2,1-3,0$ \\
\hline 4 & Managed (Planning, Organizing, Controlling) & $3,1-4,0$ \\
\hline 5 & Optimized (Best practice) & $4,1-5,0$ \\
\hline
\end{tabular}
in Table 6.

Correspondence between overall maturity level of the benchmarking class and the scale of CMM is shown

Table 6: The Overall Maturity Level of Benchmarking Class

\begin{tabular}{|l|c|c|c|}
\hline \multicolumn{1}{|c|}{ Benchmarking Class } & $\begin{array}{c}\text { Overall } \\
\text { Maturity } \\
\text { Level }\end{array}$ & $\begin{array}{c}\text { Maturity Level } \\
\text { (ML) According } \\
\text { to CMM }\end{array}$ & $\begin{array}{c}\text { Maturity Level } \\
\text { Type }\end{array}$ \\
\hline Class 1. IT management strategy and information systems planning & 1,89 & 2 & Replicable \\
\hline $\begin{array}{l}\text { Class 2. Alignment of information systems, business strategy, } \\
\text { organizational structure, and IT infrastructure. }\end{array}$ & 1,84 & 2 & Replicable \\
\hline Class 3. IT infrastructure & 3,14 & 4 & Managed \\
\hline Class 4. Information systems security management & 2,34 & 3 & Defined \\
\hline
\end{tabular}


Maturity level of the IT management process is dependent on the particular processes (i.e., structural benchmarks) that are included in every benchmarking class. This means that the relative contribution of these processes to the overall maturity level of each benchmarking class affects the IT management process maturity level. Based on the spread of maturity level shown in Table 6, it can be highlighted that reaching maturity levels 1 (Initial) and 2 (Replicable) represents the most difficult option to achieve. The Initial level is characterized by an overall lack of organized processes. At this stage, only a few processes are defined. The second level has rather detailed information on how processes are performing. Thus, companies operating at this level tend to have a fragmented view of what is taking place within their environment. The premises for applying a coherent management strategy, as well as for planning and developing IT processes, are created by reaching level 3 (Defined). On this level, companies are focused on defined, standardized, and integrated processes that allow predicting or avoiding internal events. Achieving this level generates a multiplier effect for processes, thus accelerating the attainment of maturity levels 4 (Managed) and 5 (Optimized).

As shown in Table 4, the surveyed company has an IT management process maturity level of 2; 30 out of a total level of 5 which reflects awareness rather than maturity. For the IT infrastructure benchmarking class, the maturity level is above average ( $M L=4)$, indicating the Managed type according to CMM. In other words, the company is mainly focused on technological dimension of IT activities by adopting predictable processes. These processes do not only refer to planning the development of hardware infrastructure, but also to planning and organizing the software development and IT resources. The company establishes processes concerning software applications, reconfiguration of Data Center infrastructure, rationalization of printing process, virtualization of server, and so on. Concerning the first and the second benchmarking classes, the maturity level is below average $(\mathrm{ML}=2)$, corresponding to the Replicable type of CMM. This means that although there are some actions focused on information systems planning, the company has informal procedures rather than a formal framework to develop the IT management strategy. Besides, there is no strategic integration (between IT strategy and business strategy) and functional integration (between organizational structure and IT infrastructure) based on a consistent process. The fourth benchmarking class has a maturity level above the average $(M L=3)$ which indicates the Defined type. In other words, this finding denotes the companies' interest in defining formal procedures for adopting information security practices. Unfortunately, these procedures have not yet been fully implemented.

Synthetic vision of the IT management process maturity level, indicated by the overall maturity level of each benchmarking class, is shown in Figure 2.

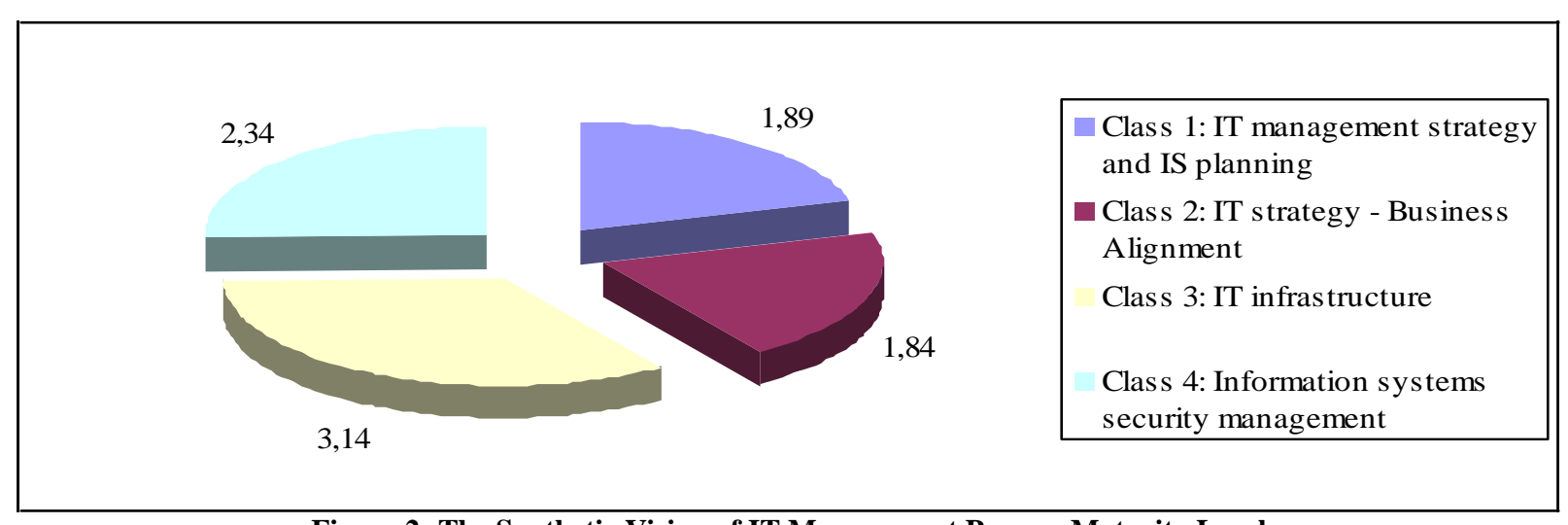

Figure 2: The Synthetic Vision of IT Management Process Maturity Level

\section{CONCLUSIONS AND RECOMMENDATIONS}

The purpose of analyzing the IT management process maturity level in a Romanian company is to provide managers an overview of positioning IT activities in the enterprise performance. Findings suggest that management of the IT function is focused on software and hardware infrastructure and less on aspects of IT business alignment or information security policy. Starting from the assumption that IT function defines the conditions of top performance, the IT management process maturity level resulting from this study should be related to the following essential 
difficulties: 1) general managers do not understand IT function while IT managers do not understand business, 2) IT activities fail in the absence of a clear business strategy aligned to IT strategy, and 3) the IT management approach is beyond a systemic vision of corporate management. In this context, several recommendations can be highlighted. First is the need to move IT managers toward planning processes in order to determine goals and the means to achieve them. Second is the increase of interest in alignment among business strategy, IT strategy, infrastructure processes, and IT infrastructure. Moreover, the implementation of information security management practices can be useful to improve the IT management process in an organization.

To address these concerns, future research should approach the development of an IT management model adapted to the profile of the organization. This could be done by using the Balanced Scorecard (BSC) as a framework for the organization to translate their strategy into a comprehensive set of Key Performance Indicators (KPI). The indicators are commonly used to help companies effectively manage and guide their progress (Kaplan \& Norton, 1992). The BSC is focused on the corporate performance measurement that makes it proper to use as a strategic management tool.

\section{AUTHOR INFORMATION}

Minodora Ursacescu received the degree in Economic Science from The Bucharest University of Economic Studies in 1991 and Ph.D degree in Management from The Bucharest University of Economic Studies, in 1997. Her current research interests include Management Information Systems, Business Economics, and Applied Information Economics. She is author and coauthor of over 40 publications including books (Information and knowledge economy (2009); ISI and Database Indexing Journals articles (Economic Computation and Economic Cybernetics Studies and Research, Review of International Comparative Management); Conference Proceedings Citation IndexScience (International Business Information Management Association -IBIMA, International Conference Accounting and Management Information Systems - AMIS). Mrs. Ursacescu is a Fellow of the Romanian Academic Society of Management. E-mail: minodora.ursacescu@ man.ase.ro

\section{REFERENCES}

1. Badawy, M. K. (1998). Technology management education: Alternative Models. California Management Review, 40(4), 94-115.

2. Baldrige Performance Excellence Program (2012). The 2011-2012 criteria for performance excellence. Retrieved from http://www.szaic.gov.cn/xxgk/qt/ztlm/szzl/zxpt/201102/P020130513520872379942.pdf

3. Choubey, M. K. (2012). IT infrastructure and management. India: Pearson Education.

4. $\quad$ Daft, R. L. (2011). Management. Mason, USA: South-Western, Cengage Learning.

5. Davenport, T. H. (1998). Putting the enterprise into the enterprise system. Harvard Business Review, 76(4), 121-131.

6. Davenport, T. H. (2000). Mission Critical: Realizing the promise of enterprise systems. Boston, MA: Harvard Business Press.

7. Goldman, S. L., Nagel, R. N., \& Preiss, K. (1995). Agile competitors and virtual organization: Strategies for enriching the customer. New York, NY: Van Nostrand Reinhold, International Thomson Publishing Inc.

8. Henderson, J., \& Venkatraman, N. (1993). Strategic Alignment: leveraging information technology for transforming organizations. IBM Systems Journal, 32(1), 4-16.

9. Ifinedo, P. (2008). Impacts of business vision, top management support, and external expertise on ERP success. Business Process Management Journal, 14(4), 551-568.

10. ISO/IEC: 27002 series (2003). Information technology - Security techniques - Code of practice for information security controls. Retrieved from http://www.iso27001 security.com/html/27002.html

11. Kaplan, R. S., \& Norton, D. P. (1992). The balanced scorecard-measures that drive performance. Harvard Business Review, 70(1), 71-79.

12. Karahanna, E., \& Watson, R.T. (2006). Information systems leadership. IEEE Transactions on Engineering Management, 53(2), 171-176.

13. Link, J. A. (2008). How to develop \& implement your IT strategy. Leicester UK: Troubador Publishing Ltd. 
14. Paulk, M. C. (1995). The evolution of the SEI's capability maturity model for software. Software Process: Improvement and Practice, 1(1), 3-15.

15. Scott Morton, M. S. (1991). The corporation in 1990's: Information technology and organizational transformation. s.l. New York, NY: Oxford University Press.

16. Somers, T. M., \& Nelson, K. G. (2004). A taxonomy of players and activities across the ERP project life cycle. Information \& Management, 41(3), 257-278.

17. Thong, J. Y. L., Yap, C. S., \& Raman, K. S. (1996). Top management support, external expertise and information systems implementation in small businesses. Information Systems Research, 7(2), 248-267.

18. Xu, J., \& Quaddus, M. (2013). Managing information systems: ten essential topics. Amsterdam: Atlantis Press. 


\section{APPENDIX}

Perception of Respondents Concerning the Maturity Level of Each Benchmarking Class

\begin{tabular}{|l|c|c|c|c|}
\hline \multirow{2}{*}{ Respondents } & \multicolumn{4}{c|}{ Benchmarking classes } \\
\cline { 2 - 5 } & Class 1 & Class 2 & Class 3 & Class 4 \\
\hline Respondent 1 & 3,02 & 3,00 & 3,25 & 3,33 \\
\hline Respondent 2 & 2,46 & 2,08 & 3,78 & 2,78 \\
\hline Respondent 3 & 1,24 & 1,47 & 2,46 & 2,57 \\
\hline Respondent 4 & 1,79 & 1,38 & 2,90 & 2,46 \\
\hline Respondent 5 & 2,63 & 1,37 & 3,89 & 3,06 \\
\hline Respondent 6 & 3,03 & 3,23 & 3,02 & 2,39 \\
\hline Respondent 7 & 1,47 & 2,39 & 2,36 & 1,81 \\
\hline Respondent 8 & 2,09 & 1,71 & 2,98 & 3,12 \\
\hline Respondent 9 & 1,68 & 1,62 & 3,16 & 2,17 \\
\hline Respondent 10 & 1,66 & 1,58 & 3,66 & 1,63 \\
\hline Respondent 11 & 2,01 & 2,16 & 3,19 & 2,03 \\
\hline Respondent 12 & 1,45 & 2,11 & 2,87 & 2,47 \\
\hline Respondent 13 & 1,34 & 1,59 & 3,68 & \\
\hline Respondent 14 & 1,66 & 2,19 & 3,74 & 1,34 \\
\hline Respondent 15 & 2,07 & 1,42 & 2,38 & 3,78 \\
\hline Respondent 16 & 2,31 & 3,13 & 2,07 \\
\hline Respondent 17 & 1,42 & 1,44 & 2,74 & 1,15 \\
\hline Respondent 18 & 1,09 & 1,12 & 3,88 & 2,91 \\
\hline Respondent 19 & 1,56 & 1,13 & $\mathbf{5 9 , 6 7}$ & \\
\hline Total & $\mathbf{3 5 , 9 8}$ & & & $\mathbf{4 4 , 5 9}$ \\
\hline
\end{tabular}


\begin{tabular}{ll} 
International Journal of Management \& Information Systems - Third Quarter $2014 \quad$ Volume 18, Number 3 \\
\hline
\end{tabular}

NOTES 